\title{
Memórias e sensibilidades numa produção de conhecimentos histórico-educacionais
}

\section{Memories and sensibilities in the production of historical and educational knowledge}

\section{Resumo:}

Neste artigo são apresentadas reflexões sobre o trabalho com memórias em um projeto desenvolvido no Museu Casa Guignard, em Ouro Preto-MG, com professores de educação básica, como parte de uma pesquisa de formação docente realizada junto ao programa de PósGraduação da Unicamp, de 2012 a 2016. Em diálogo com o filósofo Walter Benjamin, destaca-se a relação entre os sujeitos da pesquisa, potencializada pelo desafio de lidar com as sensibilidades no trabalho científico.

Palavras-chave: memórias, sensibilidades, formação docente.

\section{Abstract:}

This article presents reflections on work with memories carried out within a project developed by the Casa Guignard Museum in Ouro Preto, Minas Gerais, Brazil.

\footnotetext{
${ }^{1}$ Doutora em Educação pela Universidade Estadual de Campinas (Unicamp), professora de História na Secretaria de Estado de Educação de Minas Gerais, professora substituta de Ensino de História na Universidade Federal de Ouro Preto. Membro dos grupos de pesquisa Kairós: educação das sensibilidades, história e memória e do GEPEC: grupo de estudos e pesquisa em educação continuada, ambos vinculados à Unicamp.

2 Doutor em Linguística Aplicada pela Unicamp, professor Livre-Docente da Faculdade de Educação da Unicamp e coordenador do grupo de pesquisa GEPEC.
} 
The project involved elementary school teachers, and was carried out as part of a researchproject on teacher education of the graduate program of Unicamp from 2012 to 2016. Dialoguing with the philosopher Walter Benjamin, this article highlights the relation between the researchsubjects which are enhanced by the challenge of dealing with the scientific process.

Keywords:memories, sensibilities, teacher training.

Articular historicamente o passado não significa conhecêlo "como ele de fato foi". Significa apropriar-se de uma reminiscência, tal como ela relampeja no momento do perigo.

Walter Benjamin

\section{1- Introdução}

Entre os anos 2012 e 2015, como parte de uma pesquisa realizada junto ao Programa de Pós-Graduação em Educação da Unicamp, foi desenvolvido um projeto de formação docente continuada com professores de educação básica lotados em escolas públicas de Ouro Preto-MG, alocado no Museu Casa Guignard, nessa mesma cidade $^{3}$.

Tal projeto foi estruturado como uma pesquisa-ação (BARBIER, 2007) e visava promover um ambiente de interação que favorecesse refletir sobre formação docente, considerando uma esfera ampla de experiências vividas e buscando a percepção da docência a partir da vida dos docentes (GOODSON, 1992), expressa em fragmentos de memórias desencadeadas pelo diálogo com o espaço urbano, mediado pela obra do artista plástico Alberto da Veiga Guignard (quer seja através de suas escolhas temáticas ou técnicas, quer seja através de sua interação com a paisagem mineira, sobretudo a de Ouro Preto).

\footnotetext{
${ }^{3}$ CUNHA, Nara Rúbia de Carvalho. Primaveras Compartilhadas: (re)significando a docência na relação com cidade, memórias e linguagens. Tese (Doutorado em Educação) Faculdade de Educação, Universidade Estadual de Campinas, Campinas-SP, 2016.
} 
Articulada à vida dos docentes, a produção de narrativas verbais e visuais foi incentivada como forma de atribuição de sentidos ao que era problematizado nas diferentes atividades que compunham o projeto, como as práticas de rememoração.

As narrativas de memórias formaram um dos conjuntos documentais analisados na pesquisa e tiveram papel crucial nos encaminhamentos teóricometodológicos desse trabalho, o qual dialogou fundamentalmente com o filósofo e ensaísta Walter Benjamin.

Em um primeiro momento houve grande preocupação em favorecer as práticas de memória através de um ambiente propício à sua produção, estimulando os sentidos e as sensibilidades dos docentes. E, em seguida, na fase de análise, em função das questões que emergiram do contato com memórias afetivas, impregnadas de forte conteúdo emocional, a articulação entre memórias e sensibilidades trouxe deslocamentos para a compreensão da figura do pesquisador e da produção de conhecimentos histórico-educacionais.

Em ambos os momentos a relação entre sensibilidades e memórias estava posta como fundamental nesse trabalho. O contato com memórias de dor e luto suscitou uma reflexão sobre duas questões principais, que chamaram atenção para os cuidados que as memórias impuseram a essa produção científica. Assim, elas provocaram deslocamentos na própria concepção de produção de conhecimento, por ser necessário considerar como abarcá-las em um trabalho científico sem tomá-las como objeto sensacionalista ou silenciá-las, visto serem constituintes da vida dos docentes. E por fazer pensar sobre qual o papel do pesquisador, frente a tais memórias, num contexto de pesquisa que se pretende ético-estético-responsivo (BAKHTIN, 2010).

\section{2- Aproximação com as contribuições de Walter Benjamin}

Nessa pesquisa, havia a preocupação de inserir o processo formativo dos docentes no tempo e no espaço, enraizando-o historicamente e refletindo sobre as experiências que o constituem no contexto da modernidade. A aproximação com a 
produção de Walter Benjamin favoreceu o delineamento teórico-metodológico da pesquisa e reflexões sobre a articulação entre tempo e memória, sobre os sentidos do tempo na modernidade e sobre o lugar das memórias na produção de conhecimentos histórico-educacionais.

Em O Narrador: considerações sobre a obra de Nikolai Leskov, texto no qual analisa o declínio da arte narrativa na modernidade, Benjamin (1994) afirma que, uma vez que o tempo se torna uma grandeza econômica, a disponibilidade de dar ouvidos ao outro vai diminuindo. A narrativa tradicional, que carregava as experiências comuns, não consegue transmiti-las mais, porque carece de quem as ouça e, depois, queira contar de novo, nelas agregando as marcas de sua própria experiência.

Nesse tipo de narrativa a memória coletiva se formava com a contribuição de muitos narradores, cientes de sua finitude, portanto também cientes da necessidade de partilhar histórias. Mas, com o declínio da arte de narrar, fortemente vinculada à transformação nos ritmos do trabalho coletivo, com o declínio dos espaços comuns e do tempo de ouvir, há também o declínio da memória compartilhada.

A memória dos romances, elaborados na solidão para serem lidos na solidão, contrasta com a breve memória do narrador, porque a memória do romancista é perpetuadora de histórias singulares, enquanto a memória compartilhada é consagrada a "muitos fatos difusos" (BENJAMIN, 1994, p. 211). Assim, "o espaço infinito da memória coletiva comum encolhe, dividindo-se em lembranças avulsas de histórias particulares" (GAGNEBIN, 2014, p. 221).

A memória dos romances, chamada por Benjamin de rememoração, tem sede de lembrança porque está prenhe de esquecimento, conforme ele flagra na obra do escritor Marcel Proust. E é exatamente neste ponto que Benjamin se fixa para (re)significar a potência da rememoração para o conhecimento do vivido no tempo.

Para ele, a dimensão voluntária da memória age numa atitude deliberada de não esquecimento, que chega com as explicações, como a informação e que visa a preservar o passado. No entanto, ela se torna estéril para a experiência partilhada, porque não é nela que se fixam os elementos constitutivos do vivido, aqueles capazes de constituir as pessoas. Segundo Benjamin, é na dimensão involuntária das memórias que se podem encontrar os dados que fixam a experiência vivida, 
guardados nos domínios do esquecimento e que afluem sem serem conscientemente solicitados. Assim, o esquecimento tem um papel constitutivo importante na formação das memórias:

\begin{abstract}
Nunca podemos recuperar totalmente o que foi esquecido. E talvez seja bom assim. O choque do resgate do passado seria tão destrutivo que, no exato momento, forçosamente deixaríamos de compreender nossa saudade. Mas é por isso que a compreendemos, e tanto melhor, quanto mais profundo jaz em nós o esquecido. Tal como a palavra que ainda há pouco se achava em nossos lábios, libertaria a língua para arroubos demostênicos, assim o esquecido nos parece pesado por causa de toda a vida vivida que nos reserva. Talvez seja a mistura com a poeira de nossas moradas demolidas 0 segredo que o faz sobreviver. (BENJAMIN, 1995, p. 104-105)
\end{abstract}

Aquilo que se guarda profundamente concorre para formação dos hábitos, que frequentemente são transmitidos para outras gerações (como seiva ou como tradição). Portanto, embora a rememoração seja uma ação deliberada, intencional, suas memórias não são perfeitamente cognoscíveis, visto que elas possuem uma dupla dimensão: a da lembrança e a do esquecimento. No movimento constante de rememorar, com as memórias voluntárias vêm junto fios de memórias involuntárias, que guardam a experiência nos esconderijos do esquecimento.

As memórias permitem ao sujeito que rememora ficar frente a frente com seus hábitos, com experiências que dão sentido à sua existência e com aquilo que o (con)forma. O contato com as memórias, sobretudo as involuntárias, permite o estabelecimento de uma relação entre passado e presente com vistas a um futuro mais aberto, com certezas desestabilizadas.

Uma das imagens mais precisas de memória presentes nos textos de Benjamin está na mônada O Corcundinha, no texto Infância em Berlim por volta de 1900:

\begin{abstract}
Quando pequeno, gostava de olhar, durante os passeios, através das grades horizontais que permitiam que nos colocássemos diante de uma vitrine, mesmo quando, debaixo dela, se abrisse uma claraboia que servia para prover um pouco de luz e ar a respiradouros nas profundezas. Essas aberturas mal davam para o lado de fora; abriam-se antes para o subterrâneo. Daí a curiosidade com que olhava para baixo através das barras de cada gradeado que pisava a fim de ganhar do subterrâneo a visão de um canário, de uma lâmpada ou de um morador. Nem sempre era possível. Mas, se durante o dia fossem vãs minhas tentativas, poderia acontecer que, à
\end{abstract}


noite, a coisa se invertesse, e eu mesmo me tornasse presa em sonhos de olhares que apontavam para mim de tais aberturas. Eram gnomos de gorros pontudos que os lançavam. Porém, mal me haviam assustado até a medula, já desapareciam (...). (BENJAMIN, 1995, p. 141)

O Corcundinha (as memórias) não é apenas o que está esquecido ou guardado no passado, é aquele por quem a própria pessoa que rememora é visada. A rememoração não é um processo absolutamente controlado (tentativas durante o dia), que traz apenas o que se busca intencionalmente ou conscientemente. Não apenas o narrador tem algo a dizer (voluntariamente) de suas memórias, elas também guardam imagens dele, que afloram desprendidas de controle (surpreendem à noite).

Jeanne-Marie Gagnebin faz uma observação sobre as palavras de Benjamin, referindo-se à dimensão involuntária da memória:

\begin{abstract}
(...) A reflexão de Benjamin ressalta muito mais a novidade da imagem que nasce da mémoire involuntaire: a rigor, nunca havíamos percebido antes, ou melhor, sua visão passou despercebida quando vivíamos e só agora, graças a esse efeito de renovação do esquecimento no lembrar, e por meio da memória que não procurou por ela com vontade consciente, mas soube acolhê-la e reconhecê-la como verdadeira sem a ter antes conhecido, somente assim essa nova e antiga imagem nos faz estremecer (tressaillir, diz Proust inúmeras vezes), transformando a apreensão do nosso passado e, ao mesmo tempo, do nosso presente. (GAGNEBIN, 2014, p. 237)
\end{abstract}

Assim, na dimensão involuntária das memórias, o esquecimento permite ao sujeito que rememora ficar frente a frente com seus hábitos, com as experiências que dão sentido à sua existência e com aquilo que o (con)forma. O contato com essas memórias permite o estabelecimento de uma relação entre passado e presente com vistas a um futuro mais aberto, com certezas desestabilizadas.

Mas não se pode ter a ilusão do resgate do vivido tal qual ele aconteceu, porque o encontro com passado é mediado por uma vida percorrida no tempo. Há um intervalo de tempo entre o passado e o presente, que age sobre as sensibilidades do sujeito que rememora. Portanto, as memórias, no movimento contínuo da rememoração conseguiriam não perpetuar o vivido, mas reapresentá-lo sempre outro, porque elas não são como blocos monolíticos que contêm o acontecido no passado, mas se (re)configuram a cada encontro de temporalidades, "pois um acontecimento 
vivido é finito, ou pelo menos encerrado na esfera do vivido, ao passo que o acontecimento lembrado é sem limites" (BENJAMIN, 1994, p. 37).

Ao narrar suas memórias, em Infância em Berlim por volta de 1900, na urdidura do lembrar e do esquecer, Benjamin partilha suas experiências vividas e elas são percebidas pelo leitor, por vezes, como choques em suas sensibilidades. É o choque provocado pelas imagens involuntárias que desestabilizam sentidos, que conseguem "deter" o tempo e permitem uma abertura para outras possibilidades, pois a rememoração é capaz de trazer imagens dialéticas que se configuram no encontro de temporalidades e que conseguem interromper o fluxo contínuo da história que constantemente poderiam apresentar outras demandas para a História, outras aberturas para o passado.

Enquanto método dialético de conhecimento a rememoração é uma ação deliberada de trazer o outro à tona, numa busca incessante e assume uma função política ligada ao tempo do agora ou da agorabilidade: "acordar os mortos e juntar os fragmentos" (BENJAMIN, 1994, p. 226). Ao trazer os fios de experiências que muitas vezes são relegadas ao esquecimento ou à marginalidade, as memórias convidam ao enfrentamento de questões negligenciadas ou que se pretende encarcerar no passado, sem que tenham sido resolvidas.

Benjamin busca possibilidades de incorporação das memórias no processo de produção de conhecimento justamente naquilo que nelas há de mais específico e, para muitos considerado o mais frágil, que é sua dimensão de esquecimento, porque este filósofo, em contrapartida, compreende a importância política do trabalho de Penélope das memórias, isto é, de sempre desfazer o que havia tecido. Ao desfazer o que parecia definido, a rememoração age a contrapelo da tendência de perpetuar o particular, de submeter o que é múltiplo a uma imagem simplificadora das tensões, das ambivalências, do não concluso.

Portanto, o compromisso da rememoração não é com o resgate do passado, é com seu alargamento, no sentido de não deixar que sejam apagadas outras possibilidades que, no encontro com o presente, ainda podem ou precisam ser (re)significadas em prol de um futuro também aberto: 
Para Benjamin, rememorar é um ato político, com potencialidades de produzir um "despertar" dos sonhos, das fantasmagorias, para a construção das utopias. Rememorar significa trazer o passado vivido como opção de questionamento das relações e sensibilidades sociais, existentes também no presente, uma busca atenciosa relativa aos rumos a serem construídos no futuro. (GALZERANI, 2008C, p. 21)

$\mathrm{Na}$ relação com as considerações de Walter Benjamin, Galzerani pontua a (des)personalização das memórias, arrancadas do universo das experiências vividas e, portanto, cooptadas por um processo de educação política das sensibilidades que tem promovido a supressão dos enraizamentos espaço-temporais, ao mesmo tempo que tem perpetuado imagens do sempre igual e a sede de preencher (ou dissimular) lacunas.

Ao invés de conceber as memórias como objetos perfeitamente cognoscíveis ou de submetê-las à luz de outros conhecimentos cientificamente mais validados, Galzerni propõe aprofundar a compreensão das memórias como "meio" e "palco" de produção de saberes históricos e educacionais:

\begin{abstract}
A memória-palco é lugar, ou seja, vale-se de lugares simbólicos para se exprimir, materializar-se. Neste sentido, considero esta dimensão como própria, intrínseca à memória e não exterior a ela (...). Se conceber a memória como meio, como palco das práticas relativas à temporalidade, ela deverá envolver todos os sujeitos que participam, direta e indiretamente, neste caso, da comunidade escolar. Portanto, pressupõe uma amálgama de diferentes saberes, de diferentes dimensões, situados em diferentes vivências ou experiências vividas. Pressupõe, ao mesmo tempo interações entre diferentes temporalidades, diferentes espaços, diferentes sujeitos. (GAZERANI, 2008 B: 230)
\end{abstract}

Sob sua perspectiva, colocada em ação em práticas de pesquisa e formação, era necessário romper com a definição de lugar de memória enquanto repositório de algo que não vive mais, visto que tal definição concorre para esvaziar a memória de sua condição dinâmica de lugar e ainda tende a reforçar a crença na possibilidade de resgate do passado, como se propaga nas práticas de memória ligadas aos chamados lugares de memória (NORA, 1993).

Assim, nos dois últimos ciclos de trabalho desse projeto de formação, os docentes foram convidados a rememorar o vivido, assumindo a narrativa como resistência, inclusive contra 0 apagamento dos sujeitos e de suas práticas. No 
processo de rememoração era aberta a possibilidade de questionar sensibilidades expressas nas memórias surgidas na evocação do passado e, ao mesmo tempo, era permitido que o presente (e de certa forma o futuro) também se pronunciasse (ou que fosse reconhecido como algo que se pronuncia) no ambiente das memórias.

\section{3- Produção e partilha das narrativas de memórias}

As narrativas focalizadas neste artigo foram produzidas no projeto realizado no Museu Casa Guignard ao longo dos dois últimos ciclos do trabalho, os quais incidiram sobre memórias, narrativas e experiências vividas, contando com rodas de diálogo e oficinas temáticas.

Na primeira oficina sobre memórias, em que se trabalhou com as camadas de tempo, os docentes foram convidados a produzir pequenas narrativas (verbais ou visuais), não necessariamente lineares, de diferentes momentos de suas vidas, os quais considerassem presentes em suas sensibilidades. O suporte escolhido para essas produções foi papel de seda, uma vez que sua delicadeza exige cuidado com o manuseio e porque apresenta certa transparência. Cada narrativa deveria estar em uma folha de papel, para que depois pudesse ser organizada em camadas, dentro de um conjunto, respeitando o recorte temporal ou de intensidade conferidos a cada uma delas pelo docente. E ao serem sobrepostas, as folhas poderiam evidenciar na superfície rastros de camadas mais profundas.

A fim de expressar a forma como foi interpretada a oficina e as produções dela derivadas, da reunião dessas narrativas foi originada uma peça para exposição na Casa dos Contos de Ouro Preto (CCOP), em momento final do projeto: 


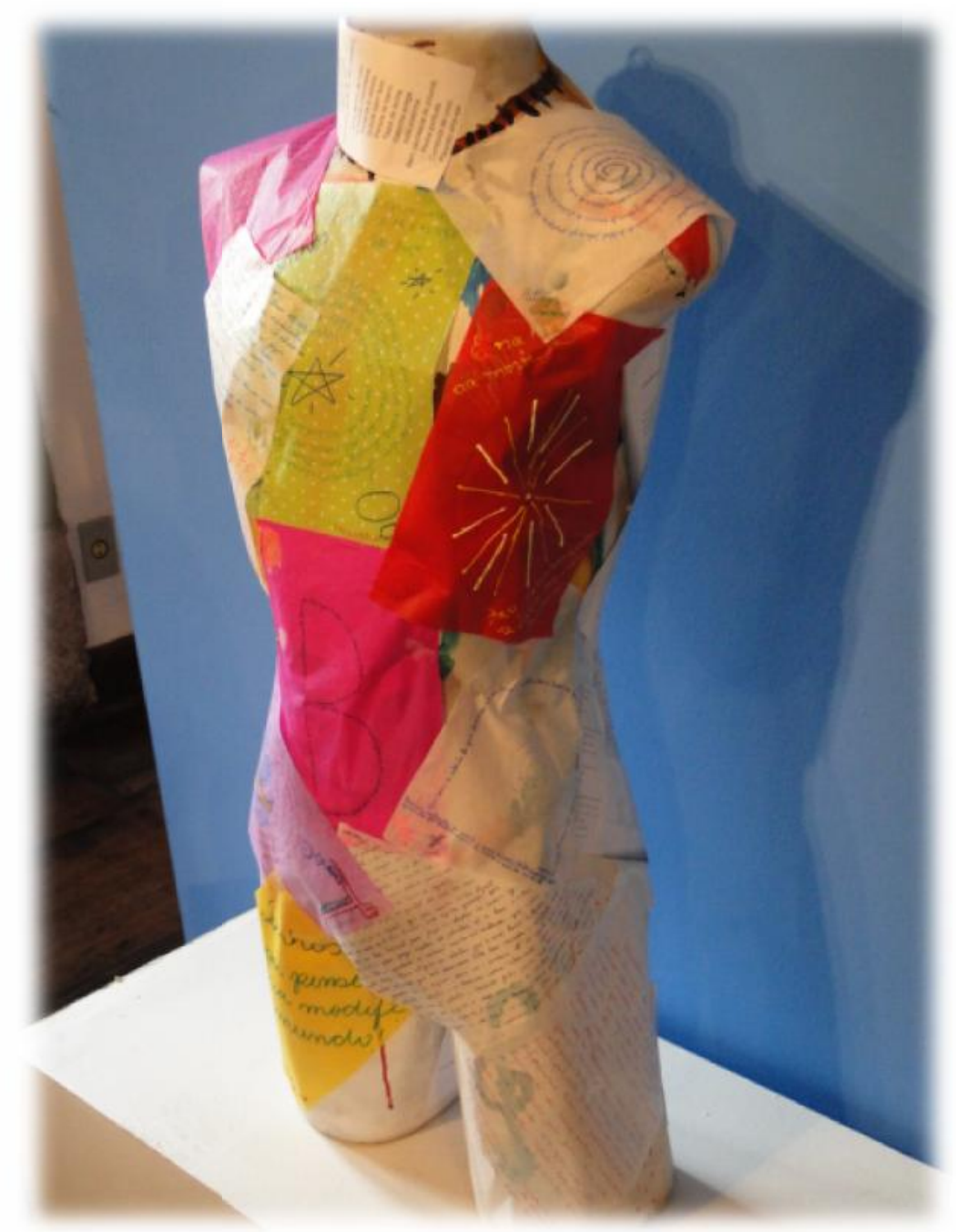

Figura 1: À Flor da Pele. Peça elaborada coletivamente pelos docentes para compor a exposição Primaveras Compartilhadas: memórias de um percurso. Ouro Preto, maio de 2013. Fotografia de Emanuele Santos (CCOP). Acervo Primaveras Compartilhadas.

Para os fins específicos deste artigo, foram transcritos alguns fragmentos de memórias que compõem essa peça:

\begin{abstract}
19 cama: Uma Lacuna
Muitos amigos, muitas atividades. Quase não saía de casa, mas aventuravame em terras desconhecidas guiada pelas palavras impressas nos livros. Os ritmos seguiam tendências familiares. A Igreja se fazia grande nas Comunidades Eclesiais de Base. Quase tudo perfeito. Corpo exausto de estudos, noites mal dormidas, muitas expectativas. Tudo começa a ruir... Fazse um clarão. Fecha-se o livro. Abre-se uma lacuna. Acordamos em 1997. Os
\end{abstract}


pedaços do sonho ainda são recolhidos após o estilhaço. (Memórias de Girassol $^{4}$. Ouro Preto, outubro de 2012. Acervo Primaveras Compartilhadas.)

\section{2a camada: Cestinha de ovos}

A quaresma era uma época em que as galinhas botavam pouco ou paravam de botar. Minha mãe quebrava a pontinha dos ovos, com todo cuidado, usava o ovo, lavava a casca e a secava. Na Semana Santa, ela e meu pai, depois que as crianças iam dormir, coloriam as cascas dos ovos, enrolando-as com papel crepom molhado. Para minha irmã mais nova, minha mãe fazia uma cestinha com caixa de sapato e papel de seda enfeitada com laços e fitas e preenchida com papel picado recheada de ovos coloridos e recheados com doce de amendoim e ovos de chocolate. Para os mais velhos e os amigos que iam dormir em casa, pratos enfeitados e cheios de ovinhos. Todos escondidos para o "Caça-ovos". Lá em casa a Páscoa tinha maior significado que o Natal. Na sexta-feira santa não se trabalhava e fazíamos jejum passando o dia com canjica branca doce. Depois que minha mãe morreu fiz a cestinha com ovos para minha irmã. Mas, já não tinha o mesmo sabor. (Memórias de Cattleya. Ouro Preto, outubro de 2012. Acervo Primaveras Compartilhadas)

\section{2 ${ }^{\text {a }}$ camada: Minha mãe, minha madrinha}

A lembrança mais viva que guardo de minha mãe biológica, e que me dói, é de estar sentada em um balcão, junto de algum irmão, enquanto ela nos oferece algum alimento que eu aceito. Em seguida, minha madrinha diz que vai sair, eu começo a chorar para não ser deixada. (Memórias de Maria-semVergonha. Ouro Preto, outubro de 2012. Acervo Primaveras Compartilhadas.)

Em outra atividade, cujo tema foi Memórias e (i)materialidade, a intenção foi desencadear um processo de rememoração a partir de objetos pessoais dos docentes.

No espaço cultural do Museu Casa Guignard foi criado um ambiente bastante acolhedor, capaz de mobilizar os diferentes órgãos dos sentidos. O espaço foi decorado com uma "chuva" de papel crepom branco e poesias que remetiam às memórias e identidades individuais, de autores como Cora Coralina, Carlos Drummond de Andrade e Fernando Pessoa, entre outros.

No fundo da sala, sob luz baixa, havia uma caixa com objetos de diferentes texturas e de uso cotidiano, que deveriam ser tocados pelos participantes com os olhos vendados, num ritual de despertar dos sentidos. Havia ainda a relaxante música ambiente Museu Casa Guignard e uma mesa preparada com quitandas mineiras.

Naquele ambiente aconchegante e receptivo, teve início a atividade proposta, que era entrar no universo de memórias dos docentes a partir de seus objetos de coleção ou de valor afetivo.

\footnotetext{
${ }^{4}$ No projeto desenvolvido cada docente adotou o nome de uma flor como pseudônimo, atendendo às exigências do Comitê de Ética em Pesquisa. Para garantir a concordância com o substantivo flores, as narrativas foram convertidas para o gênero feminino.
} 
Embora nem todos tenham levado objetos da esfera pessoal, alguns foram tirados dos baús familiares, como álbuns de fotografias. Alguns, inclusive, reveladores de memórias muito íntimas e guardadas com o mais profundo cuidado, como objetos de lembrança de momentos vividos com pessoas que não mais estão entre nós, ou que remetem a tempos que deixam marcas, como uma lancheira (que transitava entre o universo privado e a escola) guardada desde a infância "para nunca me esquecer de que quando criança eu não tinha o que colocar dentro dela para ir para escola", como foi dito pelo docente que a levou:

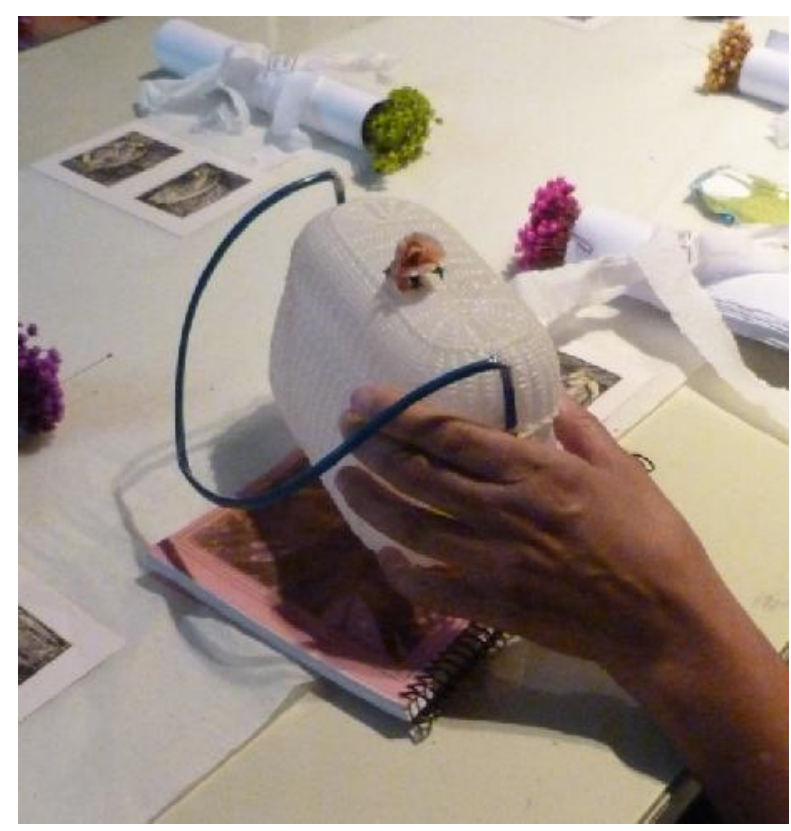

Figura 1: A lancheira. Peça destacada em partilha de memórias. Ouro Preto, dezembro de 2012. Fotografia de Caroline Conceição Souza (MCG). Acervo Primaveras Compartilhadas.

Numa terceira atividade, dedicada à elaboração de álbuns de memórias, instigava-se o trabalho com os destroços do vivido, a expressão de memórias que ocupam lugares na vida das pessoas, mas que não necessariamente estavam materializadas em algum suporte. Fomentava-se a criação de algo que pudesse traduzir o vivido e rememorado, sempre que não houvesse um objeto que o fizesse, como as fotografias. 
Vários recursos foram utilizados para materializar essas memórias, como desenhos a mão livre, poesias, textos narrativos em prosa, colagens e composições com diferentes linguagens.

Em um desses álbuns, a dor da morte se apresenta de forma contundente, como na poesia transcrita a seguir:

\section{A menininha sorria. \\ Sorria para a vida. \\ Mas nada entendia. \\ Quem era o pai? \\ Quantas mães!!}

Mãe avó.

Mãe tia.

Mãe irmã.

E a mãe, mãe?

Ah menininha... cresce!

Cresce e escolhe qual é a tua.

Se aquele que te costura.

Se aquela que te atura.

Tira de cada qual

o proveito.

Que o tempo fará eleito

Qual perfume que te ficou.

Só não pode

É perder o riso.

Que para a vida é preciso.

Pois só ele vai te curar

O que a vida te faz passar.

(Poesia do álbum de memórias de Orquídea. Ouro Preto, maio de 2013.

Acervo Primaveras Compartilhadas)

\section{4- (Des)caminhos da análise das narrativas de memórias}

$\mathrm{Na}$ fase de produção não houve um contato mais detido do pesquisador com tais narrativas, porque algumas foram entregues para análise apenas ao final do projeto, após cada docente ter tempo para amadurecer a decisão de permitir torná-las documentos de pesquisa científica.

O contato intenso com o material reunido, por um lado distante do calor das emoções que o geraram, inicialmente gerou desconforto quanto ao tratamento a ser 
dispensado a tais produções. Deveriam as memórias de dor e luto compor o texto final, uma vez que foram entregues pelos docentes? Até que ponto elas eram imprescindíveis para aquele projeto de formação docente?

Estava posto o receio de incorporar aquelas memórias ao texto final da pesquisa, pois elas traziam de forma clara um dilema a ser enfrentado pelo pesquisador que trabalha com memórias, bem traduzido na mônada Caçando Borboletas, do texto Infância em Berlim por volta de 1900, de Walter Benjamin:

Salvo viagens ocasionais no verão, instalávamo-nos anualmente, antes de eu ir para a escola, em casas de veraneio nas redondezas. Durante muito tempo, o que delas me fazia recordar era a caixa espaçosa na parede de meu quarto, com os primórdios de uma coleção de borboletas, cujos exemplares mais antigos foram capturados no jardim do Brauhausberg. Piérides da couve com bordas gastas, mariposas cor de enxofre com asas muito brilhantes, relembravam as ardorosas caçadas que tão frequentemente me atraíam dos caminhos bem cuidados do jardim para lugares ermos, onde me defrontava impotente com a conjuração do vento e dos perfumes, das folhagens e do sol, que possivelmente comandavam o vôo das borboletas. Esvoaçavam em direção a uma flor, pairavam sobre ela. Com a rede levantada, esperava tão só que o encanto, que parecia se operar da flor para aquele par de asas, cumprisse sua tarefa; então aquele corpo frágil escapava para o lado com suaves impulsos para imediatamente sombrear, imóvel, outra flor e, quase no mesmo instante, abandoná-la sem tê-la tocado. Se uma vanessa ou uma esfinge, que comodamente poderia ter alcançado, zombasse de mim com vacilações, oscilações e flutuações, então teria querido dissolver-me em luz e em ar a fim de me aproximar da presa sem ser notado e poder dominá-la. E esse desejo se fazia tão real, que lufavam sobre mim, que me irrigavam, cada agitar e cada oscilar de asas, pelos quais me apaixonava. Entre nós começava a se impor o antigo estatuto da caça: quanto mais me achegava com todas as fibras ao inseto, quanto mais assumia intimamente a essência da borboleta, tanto mais ela adotava em toda ação a matiz da decisão humana, e, por fim, era como se sua captura fosse o único preço pelo qual minha condição de homem pudesse ser reavida. Contudo, mesmo quando já a resgatara totalmente, era-me árduo percorrer o caminho entre o palco de minha ditosa caçada e minha base, onde, de um tambor de herborista, iam surgindo éter, algodão, alfinetes de cabeça colorida e pinças. $E$ em que estado ficaria aquele território às minhas costas: o capim vergado, as flores pisoteadas; ainda por cima, o caçador havia lançado o próprio corpo atrás da rede. $\mathrm{E}$ apesar de tanto estrago, tanta deselegância e violência, a borboleta assustada permanecia trêmula, e contudo cheia de graciosidade, numa dobra da rede. Era desse modo penoso que penetrava no caçador o espírito daquele ser condenado à morte. $O$ idioma no qual presenciara a comunicação entre a borboleta e as flores _só agora entendia algumas de suas leis. Sua volúpia sanguinária diminuía à medida que crescia sua confiança. (...) (BENJAMIN, 1995, p. 80-81)

Quem trabalha com memórias pode se ver nessa alegoria que Benjamin constrói. Um caçador (o pesquisador), num cenário de encontro entre borboletas (as 
memórias) e flores (os sujeitos que rememoram). As borboletas, cujo voo é comandado por uma conjunção de elementos ligados aos sentidos, têm encontros efêmeros com as flores, muito mal compreendidos pelo caçador, porque seu interesse é dominar a presa, é se sobrepor a ela. Na mônada focalizada, as flores não interessam ao caçador, embora sejam elas as responsáveis por exalar o perfume que atrai as borboletas. A empreitada do caçador termina quando ele finalmente define 0 destino da borboleta e a sepulta em uma caixa, como um troféu, à revelia de todo estrago e sofrimento causados por ele, inclusive a si mesmo.

As imagens que se depreendem de tal mônada permitem comunicar ao leitor a experiência com as narrativas de memórias na pesquisa aqui focalizada.

As memórias são elementos sensíveis e que exigem um trato sensível. Ao mesmo tempo, dado o teor emocional das memórias, com o qual por vezes o pesquisador se envolve, é necessário que o pesquisador esteja sempre atento à sua condição, que por vezes precisa ser reavida. Por outro lado, em consonância com a crítica de Walter Benjamin, é necessário não se embrenhar numa luta que possa destruir os sujeitos da pesquisa, através do apagamento de suas palavras, quer sejam os sujeitos que produzem as fontes, quer seja o sujeito que as analisa. E é preciso evitar submeter as memórias ao alfinete, relegando-as à condição de objetos a serem depositados sem vida numa caixa emoldurada.

A fim de evitar o risco de empreender uma relação marcada pela volúpia sanguinária, teve-se em mente que era preciso estar em vigília para não perder aquele último momento de esperança, quando a borboleta, embora assustada, ainda se mantém trêmula e graciosa. Compreendia-se, na relação com a narrativa de Benjamin, que seria necessário captar o potencial das reminiscências, ainda que fugidias, para que a vida nelas contida pudesse ser respeitada e problematizada. Mas, para isso, era um dever perder o medo de tocá-las.

Ao invés de conceber as memórias como objetos perfeitamente cognoscíveis ou de submetê-las à luz de outros conhecimentos cientificamente mais validados, o caminho metodológico que foi se definindo na análise buscou inventariar essas memórias, inserindo-as no tempo e no espaço e empreender uma relação tátil com as mesmas, isto é, uma leitura que permite ao pesquisador nelas imergir para depois emergir enriquecido do contato com o outro (GALZERANI, 2013). 


\section{5- Uma leitura possível das narrativas de memórias}

Focalizando as memórias apresentadas neste texto, percebe-se que numa de suas camadas de memória (Minha mãe, minha madrinha) Maria-sem-Vergonha apresenta como experiência à flor de sua pele a lembrança mais viva que guarda de sua mãe, falecida quando ela ainda era criança. A cena delineia a imagem de uma separação, tendo no primeiro plano um momento de carinho entre mãe e filhos.

A cena envolve o leitor até o ponto em que, de repente, a narrativa é interrompida. A criança chorava para não ser separada da mãe ou da madrinha? Esta informação não está clara na narrativa. Mas a resposta talvez fosse irrelevante para o trabalho daquela memória. O texto foi interrompido exatamente onde a lembrança se aloja: numa dor diante da separação, da impotência, da irreversibilidade do tempo, da finitude. Para os propósitos dessa pesquisa, a cena carece de interpretações ou de ouvidos?

A narrativa de Girassol (Uma lacuna) faz uso da linguagem para nomear a lacuna que sua dor mantém, forçando à leitura do que foi silenciado.

Nas memórias de Cattléya (Cestinha de ovos) a morte se apresenta como experiência cravada em sua pele. A adolescente que busca lidar com a falta da mãe, tentando minimizar o sofrimento da irmã, percebe que os ovinhos de Páscoa já não tinham o mesmo sabor. É uma cena de impotência, que se configura diante de leitor como um imenso campo vazio, mudo, com o narrador ao centro.

As memórias de dor morte passam por pequenas frestas em e entre as palavras desses docentes, mas são suficientes para marcar presença e convidar à (re)significação. O mesmo ocorre na narrativa de Orquídea (em seu álbum de memórias) quando ela se refere à falta da mãe. É numa frase curta que sinaliza uma presença ausente: "E a mãe, mãe?".

Ao enraizá-las no tempo e no espaço, essas memórias trazem imagens valiosas para uma reflexão sobre as sensibilidades relativas ao tempo na modernidade capitalista. 
Primeiramente, a dimensão linear do tempo é quebrada de forma abrupta nas sensibilidades dos sujeitos que vivem a experiência da morte e as narrativas expressam essa quebra na linguagem. As narrativas expressam a suspensão dos sentidos e a imagem (o vazio) que permanece após o ocorrido. São imagens de dores que, de certo modo, encarceram o vivido nos sujeitos. O tempo aparece estático, enquanto a dor fica latente, percorrendo o corpo.

A leitura dessa dor pode levar ao pensamento sobre como é vivida a experiência da finitude na contemporaneidade. Segundo Walter Benjamin (1994 e 2006), o fato de afastar as imagens de morte das experiências cotidianas tem favorecido uma dificuldade de compreender a morte e a própria vida, isto é, a vida para além dos planos, da previsibilidade, do controle, do visível. Considera-se desde as práticas que afastam os moribundos do convívio dos saudáveis à sobreposição do inorgânico ao orgânico, como construção de sensibilidades que negam a morte: da beleza, da virilidade, da fertilidade, do corpo. Práticas culturais que têm impedido de lidar com a morte.

Dentro do projeto focalizado, essas narrativas de memórias contribuíram para pensar a urgência de aprender a lidar com o tempo enquanto intensidade e com a vida como algo que escapa. Ao mesmo tempo, evidenciou a urgência de se pensar a formação humana, rompendo com uma visão abstrata de tempo e de ser humano.

Sob o impacto dessas narrativas de dor e luto, foi possível perceber os desafios e a riqueza do trabalho com as memórias. Independentemente do conteúdo, o que se configurou foi um trabalho (CHAUí, 1994) que demandou e demanda sensibilidade. Trabalho social de lembrança, de evocação, de reelaboração do vivido (BOSI, 1994); trabalho de partilha (BENJAMIN, 1994;1995); trabalho de formação atento aos rumos do futuro (GALZERANI, 2008A); trabalho de fazer-se no vivido e de (re)fazer-se a partir dele (PAIM, 2005); trabalho de escuta, translaboração, esquecimento, luto, perdão (RICOUER, 2007; s/d) que impõe focalizar presente, passado e futuro imbricados.

Para Paul Ricouer, o trabalho de translaboração, isto é, de elaboração, reinterpretação e cicatrização do passado, coloca a pessoa diante da exigência de romper com um "preconceito tenaz" sobre o passado. Não é possível compreendê-lo como algo fechado: 


\begin{abstract}
Mas, ao invés, o sentido do que nos aconteceu, quer tenhamos sido nós a fazê-lo, quer tenhamos sido nós a sofrê-lo, não está estabelecido de uma vez por todas. Não só os acontecimentos do passado permanecem abertos a novas interpretações, como também se dá uma reviravolta nos nossos projectos, em função das nossas lembranças, por um notável efeito de 'acerto de contas'. O que do passado pode então ser mudado é a carga moral, o seu peso de dívida, o qual pesa ao mesmo tempo sobre o projecto e sobre o presente. (RICOUER, s/d, p. 4-5)
\end{abstract}

As palavras de Ricouer vão ao encontro da potencialidade que Benjamin percebia no trabalho com as memórias, pela rememoração. Um trabalho de questionamento do presente e do passado, pela escavação infindável do passado, e com vistas à construção de outros futuros.

Nesses movimentos, o que se depreende dessas narrativas não é um trabalho individual de cicatrização de feridas pontuais, por mais profundas que sejam, mas um trabalho coletivo e político, de despertar no tempo, com o tempo, para o outro, com o outro.

O contato com essas narrativas promoveu uma atitude de escuta por parte do pesquisador, um "escutar/ver" em que o pesquisador "deve saber sentir o universo afetivo, imaginário e cognitivo do outro para "compreender do interior'” (BARBIER, 2011, p. 94), o que segundo Barbier é algo necessário em pesquisas que enveredam pela complexidade do humano.

Assim, nesse projeto de formação docente, o trabalho com memórias e sensibilidades favoreceu a formação do próprio pesquisador, permitindo compreender que a autoridade do pesquisador, necessária para trabalhar com as memórias respeitando a vida, é sua própria condição humana, capaz de permitir a ele uma correspondência com o outro.

\section{Referências}

BAKTHIN, Mikhail. Para uma filosofia do ato responsável. São

Carlos-SP: Pedro \& João Editores, 2010. 
BARBIER, René. A Pesquisa-Ação. Tradução de Lucie Didio. Brasília: Liber Livro Editora, 2007.

BENJANIN, Walter. Magia e Técnica, arte e política: ensaios sobre literatura e história da cultura. Tradução de Sérgio Paulo Rouanet. 7 ed. São Paulo: Brasiliense, 1994.

Rua de Mão Única. Tradução de Rubens Rodrigues Torres Filho e José Carlos Martins Barbosa. 5 ed. São Paulo: Brasiliense, 1995.

BOSI, Ecléa. Memória e sociedade: Lembranças dos velhos. São Paulo: Companhia das Letras, 1994.

CHAUÍ, Marilena. Os trabalhos da memória. In: BOSI, Ecléa. Memória e sociedade: Lembranças dos velhos. São Paulo: Companhia das Letras, 1994. (Apresentação)

GAGNEBIN, Jeanne-Marie. Limiar, aura e rememoração: ensaios sobre Walter Benjamin. São Paulo: Editora 34, 2014.

GALZERANI, Maria Carolina Bovério. Entrelazando conocimientos, memorias y práctivas educativas: una producción de culturas docentes. In: PARDO, Maria Benedita lima; GALZERANI, Maria Carolina Bovério e LOPES, Amélia (orgs.). Una "nueva" cultura para la formación de maestros: ¿Es posible?. Porto: Livpsic/AMSEAMCE-WAER, 2008(A). p. 15-38.

A produção de saberes históricos escolares: o lugar das memórias. In: FERREIRA, Antonio Celso - BEZERRA, Holien Gonçalves - LUCA, Tania Regina de (Orgs.) O Historiador e seu tempo. São Paulo: Ed. UNESP, p.223-235, 2008(B).

. Memória, história e tempo: perspectivas teóricometodológicas para a pesquisa em ensino de história. Cadernos do CEOM, v.21, n.28, p.15-32, jun.2008(C).

Imagens que lampejam: contribuições de Walter Benjamin para a produção de conhecimentos históricos. Encuentro de Saberes. Luchas populares, resistências $Y$ educación, Buenos AiresArgentina, v. 1, n. 2, p. 53-57, 2013. 
GOODSON, Ivor. Dar voz ao professor: as histórias de vida dos professores e o seu desenvolvimento profissional. In: NOVOA, António (Org.). Vidas de professores. Porto: Editora Porto, 1992.

LE GOFF, Jacques. História e Memória. Campinas-SP: Editora da UNICANP, 2004.

NORA, Pierre. Entre Memória e História: a problemática dos lugares. Projeto História, v.10, dez. 1993.

PAIM, Elison Antônio. Memórias e experiências do fazer-se professor. Tese (Doutorado em Educação) Faculdade de Educação da Unicamp, Campinas-SP, 2005.

RICOUER, Paul. O perdão pode curar? Lisboa: Luso Sofia, s/d. Disponível em: http://www.lusosofia.net/textos/paul_ricoeur_o_perdao_pode_curar.p df (Último acesso em maio de 2016) 